\title{
Gambaran Klinis dan Respon Imun Penderita Demam Berdarah Dengue di Rumah Sakit Kristen Lindi Mara Sumba Timur Selama Bulan Januari Sampai Dengan Desember 2018
}

\section{Clinical Features and Immune Response on Dengue Hemorrhagic Fever Patients in Lindi Mara Christian Hospital Eastern Sumba, During January to December 2018}

\author{
Ruben Wadu Wila*, Roy Nusa \\ Loka Penelitian dan Pengembangan Kesehatan Waikabubak, Badan Litbang Kesehatan, \\ Kementerian Kesehatan RI \\ Jalan Basuki Rahmat Km 5 Puuweri Waikabubak Sumba Barat, Nusa Tenggara Timur, Indonesia \\ *E_mail: rubenwadu14@gmail.com
}

Received date: 18-02-2020, Revised date: 12-11-2020, Accepted date: 17-11-2020

\begin{abstract}
ABSTRAK
Demam berdarah Dengue (DBD) adalah penyakit arboviral yang tersebar luas di seluruh dunia. Virus Dengue menular ke manusia melalui gigitan nyamuk Aedes betina yang telah terinfeksi. Infeksi dari salah satu serotipe virus pada mayoritas kasus terkadang tidak menimbulkan gejala atau bisa menimbulkan gejala klinis. Infeksi virus Dengue menyebabkan tubuh merespon secara klinis dan membentuk antibodi. Penelitian ini bertujuan untuk memberikan gambaran klinis dan respon imun pada penderita Demam Berdarah Dengue. Artikel ini menggunakan desain studi observasional terhadap data sekunder hasil pemeriksaan serologi IgM dan IgG dari 52 penderita infeksi DBD di Rumah Sakit Lindi Mara tahun 2018. Hasil analisis deskriptif menunjukkan penderita DBD laki-laki sebanyak 55,8\%, dan umur terbanyak pada remaja yaitu 34,6\%. Gambaran klinis terbanyak adalah demam $91,4 \%$; sakit kepala $24,0 \%$; nyeri telan $20,8 \%$; muntah $21,8 \%$; dan nyeri ulu hati 18,7\%. Pemeriksaan serologis menunjukkan 19,2\% positif IgM; 36,5\% IgG; dan sebanyak 44,2\% positif IgM dan IgG. Infeksi virus Dengue pada 52 penderita di Kabupaten Sumba Timur sebagian besar merupakan infeksi sekunder $(80,8 \%)$ dengan kelompok umur yang paling banyak terinfeksi adalah kelompok dewasa ( $\geq 16$ tahun).
\end{abstract}

Kata kunci: Demam Berdarah Dengue, serologi, IgM, IgG, Sumba Timur

\begin{abstract}
Dengue hemorrhagic fever (DHF) is an arboviral disease that is widespread worldwide. Dengue virus is transmitted to humans through the bite of an infected female Aedes mosquito. Infection of one of the viral serotypes in the majority of cases causes no symptoms or may cause clinical symptoms. Dengue virus infection causes the body to respond clinically and form antibodies. This research study is to provide clinical features and immune response in patients with Dengue hemorrhagic fever. This article uses an observational study design of secondary data of both IgM and IgG sequential examinations of 52 people with Dengue hemorrhagic fever infections at Lindi maria hospital in 2018.The results of the descriptive analysis showed that male population with Dengue hemorrhagic fever was $55.8 \%$, and the highest rate of infection was in adolescents $34.6 \%$. The most clinical features found were fever 91.4\%; headache 24.0\%; swallow pain 20.8\%; vomiting $21.8 \%$; and gastric pain $18.7 \%$. Serological examination showed $19.2 \%$ positive IgM; $36.5 \%$ IgG; and $44.2 \%$ positive both IgM and IgG. The Dengue virus infection in 52 patients in East Sumba is mostly secondary infection (80.8\%) with the most infected age group is the adult group ( $\geq 16$ years old).
\end{abstract}

Keywords: Dengue Hemorrhagic fever, serology, IgM, IgG, Eastern Sumba 


\section{PENDAHULUAN}

Angka kesakitan akibat DBD di Indonesia masih tinggi, pada tahun 2018 sebanyak 65.602 kasus dengan jumlah kematian 467 orang. Jumlah tersebut menurun dari tahun sebelumnya, yaitu 68.407 kasus dan jumlah kematian sebanyak 493 orang. Angka kesakitan akibat DBD di provinsi Nusa Tenggara Timur masih cukup tinggi pada tahun 2018 sebesar 24,8/100.000 penduduk, dan pada tahun 2017 sebesar 10,3/100.000 penduduk dan pada tahun 2016 sebanyak 23,3/100.000 penduduk. Salah satu kabupaten dengan jumlah kasus DBD cukup tinggi adalah Kabupaten Sumba Timur. Jumlah angka kesakitan akibat DBD di kabupaten Sumba Timur tahun 2018 sebanyak 67,8/100.000 penduduk dengan Case Fatality Rate (CFR) sebesar $1,16 \%$ jumlah ini lebih tinggi dibandingkan dengan tahun 2017 sebesar 54,6/ 100.000 penduduk.

Pedoman untuk menegakkan diagnosis DBD adalah dengan menggunakan kriteria yang disusun oleh World Health Organization (WHO) tahun 2009 yang terdiri dari kriteria klinis dan laboratorium. Kriteria klinis yang digunakan terdiri dari demam tinggi yang berlangsung terus-menerus tanpa penyebab yang jelas, adanya manifestasi perdarahan, hepatomegali dan adanya syok. ${ }^{1,2}$

Kriteria laboratorium terdiri dari trombositopenia, adanya kebocoran plasma atau hemokonsentrasi. Perubahan ini sering terjadi pada hari ke-3 hingga ke-5 demam. Perjalanan penyakit bisa sangat cepat dalam beberapa hari, bahkan dalam hitungan jam penderita bisa masuk dalam keadaan kritis. Untuk menghindari keterlambatan diagnosis, deteksi awal infeksi virus ini adalah hal yang sangat krusial. ${ }^{3}$

Infeksi virus Dengue akan memicu tubuh untuk menghasilkan respon imun, salah satunya adalah terbentuknya Imunoglobulin. Salah satu unsur diagnosis DBD dilakukan berdasarkan hasil pemeriksaan serologis antibodi IgM dan IgG spesifik Dengue.,
Analisis yang dilakukan adalah mengidentifikasi antibodi spesifik virus Dengue imunoglobulin M (IgM) untuk infeksi Dengue primer dan imunoglobulin $\mathrm{G}$ ( $\mathrm{IgG}$ ) untuk infeksi Dengue sekunder. Tujuan penulisan artikel ini adalah untuk memberikan gambaran klinis dan respon imun penderita demam berdarah Dengue di Rumah Sakit Kristen Lindi Mara Sumba Timur dari bulan Januari sampai dengan Desember 2018.

\section{METODE}

Penelitian ini merupakan penelitian deskriptif dengan menganalisis data sekunder penderita DBD di Rumah Sakit Kristen Lindi Mara Sumba Timur dari bulan Januari sampai dengan Desember 2018. Pengumpulan data berasal dari Dinas Kesehatan Kabupaten Sumba Timur terkait dengan karakteristik penderita DBD. Sementara hasil pemeriksaan IgM dan IgG diperoleh dari Rumah Sakit Lindi Mara.

Kriteria inklusi adalah penderita yang terdiagnosis DBD dengan penegakan pemeriksaan klinis dan laboratoris (IgG dan IgM) dari Januari sampai dengan Desember 2018. Kriteria eksklusi adalah penderita DBD yang data rekam medisnya tidak lengkap atau hilang. Data rekam medis yang sesuai kriteria inklusi dimasukkan dalam sampel penelitian. Sebanyak 52 penderita DBD yang diperoleh dengan menggunakan metode total sampling diikutkan dalam penelitian ini. Analisis data dilakukan secara deskriptif dan disajikan dalam bentuk tabel frekuensi.

\section{HASIL}

Penegakan diagnosis DBD didapatkan dari gejala klinis dan pemeriksaan laboratorium yaitu pemeriksaan hemoglobin, hematokrit, tormbosit, lekosit, eritrosit dan pemeriksaan antibodi virus Dengue $\operatorname{IgM}$ dan $\mathrm{IgG}$ serta pemeriksaan NS1. Karakteristik responden dari 52 penderita yang dilakukan pemeriksaan serologis $\operatorname{IgM}$ dan $\operatorname{IgG}$ adalah sebagai berikut: 
Tabel 1. Distribusi Penderita Demam Berdarah Dengue (DBD) Berdasarkan Jenis Kelamin dan Kelompok Umur di Rumah Sakit Kristen Lindi Mara Sumba Timur Bulan Januari - Desember 2018 (n= 52)

\begin{tabular}{|c|c|c|}
\hline Variabel & Jumlah & $(\%)$ \\
\hline Jenis kelamin & & \\
\hline Laki-laki & 29 & 55,8 \\
\hline Perempuan & 23 & 44,2 \\
\hline Kelompok umur & & \\
\hline Balita (0-4 tahun) & 9 & 17,3 \\
\hline Anak-anak (5-15 tahun) & 9 & 17,3 \\
\hline Dewasa ( $\geq 16$ tahun) & 34 & 65,4 \\
\hline
\end{tabular}

Distribusi jumlah pasien DBD berdasarkan jenis kelamin dapat dilihat bahwa jenis kelamin hampir sama banyak antara lakilaki dan jenis kelamin perempuan. Kelompok umur terbanyak yaitu dewasa sebanyak $65,4 \%$, umur balita dan anak-anak yaitu sebanyak $17,3 \%$.

Tabel 2. Gejala Klinis Penderita Demam Berdarah Dengue di Rumah Sakit Kristen Lindi Mara Sumba Timur Bulan Januari - Desember 2018

\begin{tabular}{|c|c|}
\hline Gejala klinis & $(\mathrm{n}=52) \%$ \\
\hline Demam & 91,4 \\
\hline Sakit kepala & 24,0 \\
\hline Nyeri otot & 0 \\
\hline Nyeri sendi & 3,5 \\
\hline Nyeri telan & 20,8 \\
\hline Batuk & 9,3 \\
\hline Pilek & 3,1 \\
\hline Mual & 21,8 \\
\hline Muntah & 20,6 \\
\hline Diare & 9,3 \\
\hline Nyeri ulu hati & 19,6 \\
\hline Lemas & 3,3 \\
\hline \multicolumn{2}{|l|}{ Pendarahan spontan } \\
\hline Mimisan & 9,3 \\
\hline Kulit & 12,5 \\
\hline Gusi & 0 \\
\hline Tinja & 0 \\
\hline Konjutiva & 0 \\
\hline \multicolumn{2}{|l|}{ Pemeriksaan fisik/tanda klinis } \\
\hline Ruam kulit & 3,1 \\
\hline Anemis & 0 \\
\hline Sklera ikteris & 0 \\
\hline Efusiplura & 0 \\
\hline Sesak nafas & 0 \\
\hline
\end{tabular}


Tabel 2 menunjukkan bahwa gejala klinis utama penderita DBD yang datang memeriksakan diri di Rumah Sakit Kristen Lindi Mara Kabupaten Sumba timur adalah demam. Gambaran klinis yang cukup banyak adalah sakit kepala, nyeri telan, muntah, dan nyeri ulu hati. Pendarahan spontan terbanyak adalah pendarahan pada kulit dan mimisan serta pada pemeriksaan fisik ditemukan ruam pada kulit pada penderita.

Tabel 3. Hasil Pemeriksaan Serologi pada Penderita Demam Berdarah Dengue di Rumah Sakit Kristen Lindi Mara Sumba Timur Bulan Januari - Desember 2018 (n $=52$ )

\begin{tabular}{llc}
\hline Respon Imun & Jumlah & $(\%)$ \\
\hline IgM Positif & 10 & 19,2 \\
IgG Positif & 19 & 36,5 \\
IgM dan IgG Positif & 23 & 44,2 \\
\hline
\end{tabular}

Hasil pemeriksaan serologi terhadap 52 orang penderita DBD diperoleh hasil merupakan positif IgM, dan positif IgG, dan positif keduanya yaitu IgM dan IgG positif. Hasil uji serologi sebanyak 10 orang (19,2\%), merupakan infeksi primer (IgM Positif) yang menunjukkan baru pertama kali terinfeksi virus Dengue dan terdapat 42 orang atau $80,7 \%$ infeksi sekunder (IgG positif dengan IgM positif atau negatif).

\section{PEMBAHASAN}

Infeksi DBD lebih banyak pada lakilaki yaitu sebanyak 55,8\% jika dibandingkan dengan pada perempuan yaitu sebanyak $44,2 \%$. Hasil ini berbeda dengan penelitian yang dilakukan di Kota Semarang tahun 2019 yang menyatakan bahwa penderita DBD perempuan lebih banyak daripada laki-laki. ${ }^{6}$ Sedangkan hasil penelitian di Kabupaten Ogan Komerin Ulu menyatakan jumlah penderita DBD hampir sama banyak antara perempuan dan laki-laki. ${ }^{7}$ Penelitian lain juga menyatakan bahwa perempuan lebih banyak menderita DBD dibandingkan laki laki. ${ }^{8,9}$ Perbedaan hasil tersebut kemungkinan disebabkan oleh keterbatasan data yang ditampilkan yaitu hanya pada penderita yang dilakukan pemeriksaan IgM dan IgG. Virus Dengue dapat menyerang siapa saja baik perempuan dan laki-laki sama-sama mempunyai resiko untuk tertular. Dengan kata lain dapat dijelaskan bahwa laki-laki dan perempuan mempunyai peluang yang sama terjangkitnya DBD dan perbedaan jenis kelamin tidak berpengaruh terhadap berat ringannya penyakit DBD.

Kelompok umur yang paling banyak terkena infeksi DBD adalah kelompok dewasa sebanyak $65,4 \%$. Kelompok ini merupakan kelompok usia produktif yang mempunyai tingkat mobilisasi yang tinggi. Penelitian lain yang dilakukan di Bali dan Bukit Tinggi menyatakan bahwa kelompok usia $>15$ merupakan kelomok umur yang paling banyak terkena DBD. ${ }^{10,11}$ Hasil penelitian ini berbeda dengan penelitian Raiban di Jakarta yang menyatakan bahwa kelompok usia 5 sampai dengan 10 tahun merupakan kelompok usia yang paling banyak terinfeksi virus Dengue. Penelitian tersebut juga menyatakan bahwa pasien DBD yang berumur dibawah 15 mempunyai derajat keparahan yang cenderung lebih tinggi. Makin muda usia makin tinggi pula mortalitasnya. ${ }^{12}$

Kejadian DBD di Kabupaten Sumba Timur sebagian besar adalah pada kelompok usia lebih dari 15 tahun. Hal ini mungkin disebabkan karena kelompok usia $>15$ tahun merupakan kelompok usia produktif yang memiliki tingkat mobilitas relatif lebih tinggi sehingga rentan untuk kontak dengan nyamuk Aedes sp. yang terinfeksi. ${ }^{13}$

Gambaran klinis utama penderita DBD di rumah sakit di Kabupaten Sumba Timur adalah demam, sakit kepala, nyeri telan, muntah, nyeri ulu hati, pendarahan spontan pada kulit dan mimisan serta ditemukan ruam pada kulit.

Pada infeksi DBD, manifestasi klinis yang muncul sangat bervariasi sehingga diagnosis klinis awal DBD sering sulit ditegakkan. Gejala klinis yang paling dominan 
muncul adalah demam. Demam merupakan respon dari pertahanan tubuh terhadap serangan virus Dengue. Selain demam, penelitian lain di Sulawesi Tengah melaporkan $50 \%$ penderita mengalami mual dan muntah; dan hampir semua penderita mempunyai gejala sakit kepala dan nyeri perut. ${ }^{14}$

Penderita DBD lebih dominan mengalami infeksi sekunder dibandingkan primer, hal ini menunjukkan bahwa pasien terkena infeksi untuk yang kedua kalinya oleh virus yang sama dari serotipe yang berbeda. Penelitian ini sejalan dengan penelitian yang pernah dilakukan di Denpasar Bali yang menyatakan bahwa jenis infeksi sekunder lebih banyak jika dibandingkan dengan infeksi primer. ${ }^{15}$ Pada infeksi primer, pemeriksaan antibodi IgM akan menunjukkan hasil yang positif setelah sekitar 4 sampai 5 hari dari munculnya gejala demam. IgM anti Dengue merupakan antibodi primer pada penderita yang terinfeksi virus Dengue pertama kali. Kadar IgM akan meningkat selama 1-3 minggu infeksi. IgM akan mencapai kadar puncak sekitar hari ke-14 setelah onset, kemudian kadarnya akan turun dan bertahan hingga 3 bulan. ${ }^{16}$

$$
\text { Pembentukan immunoglobulin }
$$

(khususnya IgM) di awal saat virus Dengue masuk ke dalam tubuh berperan untuk mengeliminasi virus. Keberadaan proses ini dapat memperingan penyakit selama kadar IgM cukup banyak. Jika kadar IgM rendah, infeksi akan berjalan lebih berat karena proses eliminasi virus tidak memadai. ${ }^{15,17}$

IgM biasanya tetap berada dalam saluran peredaran darah dan tidak berdifusi kedalam jaringan tubuh dan dapat menyebabkan aglutinasi berbagai partikel fiksasi komplemen dengan efisiensi yang sangat tinggi. IgM mempunyai aviditas yang tinggi terhadap antigen yang mempunyai multideterminan antigen. IgM bila ditemukan kadarnya akan lebih rendah dan biasanya tidak melebihi kadar IgG. ${ }^{18}$ Infeksi primer sering bersifat subklinis sehingga jumlah kasus rawat inap di rumah sakit cenderung kurang dibandingkan dengan infeksi sekunder yang gejala penyakitnya lebih berat. Pemberian informasi dan edukasi kepada masyarakat tentang penyakit DBD sangat membantu dalam menemukan kasus baru DBD dan ini mengurangi risiko penyakit menjadi lebih berat oleh karena penanganan dapat segera dilaksanakan. ${ }^{16}$

Antibodi IgG menunjukkan hasil positif pada infeksi sekunder yang juga bisa disertai dengan antibodi IgM yang kemungkinan dapat menunjukkan hasil yang positif ataupun negatif. ${ }^{16}$

Jika gambaran serologis menunjukkan adanya infeksi sekunder, di mana hanya IgG saja yang terdeteksi maka diagnosis harus didukung dengan melihat klinis dan pemeriksaan hasil laboratorium darah lengkap berdasarkan kriteria WHO. Hal ini dapat terjadi karena $\mathrm{IgG}$ pada infeksi sekunder secara signifikan lebih rendah daripada infeksi primer sehingga tidak terdeteksi pada beberapa kasus. ${ }^{19,20}$

Pada infeksi sekunder Dengue, terjadi peningkatan titer antibodi IgG secara tiba-tiba sehingga infeksi sekunder umumnya memberikan gejala klinis yang berat. Hasil positif dari IgG menunjukkan adanya suatu infeksi yang berulang atau pernah terjangkit sebelumnya. Dalam serum orang dewasa normal IgG merupakan $80 \%$ dari total antibodi yang terdapat dalam serum. ${ }^{21}$ IgG dapat menembus jaringan plasenta dan dapat memberikan proteksi utama pada bayi terhadap infeksi selama beberapa minggu pertama setelah lahir. IgG lebih mudah menembus saluran darah dan berdifusi kedalam jaringan ekstravaskuler. ${ }^{18}$

\section{KESIMPULAN}

Infeksi virus Dengue pada penderita DBD sebagian besar terjadi pada laki-laki dengan kelompok usia dewasa, gejala klinis yang paling utama adalah demam, sakit kepala, mual, muntah dan nyeri waktu menelan serta sebagian besar merupakan infeksi sekunder. 


\section{SARAN}

Penanganan DBD terutama infeksi sekunder harus diwaspadai, kecenderungan ke arah infeksi Dengue lebih berat. Dengan demikian uji serologis sebaiknya dilakukan sebagai sarana diagnosis dini DBD.

\section{KONTRIBUSI PENULIS}

Kontributor setiap penulis dalam artikel ini adalah RWW sebagai kontributor utama bertanggung jawab dalam konsep penulisan artikel secara menyeluruh serta analisis dan penyajian data $\mathrm{RN}$ sebagai kontributor anggota bertanggung jawab dalam memberikan masukan terhadap konsep gambaran klinis dan respon imun penderita DBD.

\section{UCAPAN TERIMA KASIH}

Pada kesempatan ini penulis mengucapkan terima kasih kepada Kepala Dinas Kesehatan Kabupaten Sumba Timur, Pengelola Program Demam Derdarah Dengue Dinas Kesehatan Kabupaten Sumba Timur yang telah mendukung penulis dalam menyediakan data kejadian DBD di Kabupaten Sumba Timur. Penulis juga mengucapkan terima kasih yang sebesar-besarnya kepada semua rekan-rekan yang telah memberikan motivasi kepada penulis untuk menyelesaikan penulisan artikel ini.

\section{DAFTAR PUSTAKA}

1. Indrawan MA, Muhyi A, Leatemia DL. Gambaran hasil pemeriksaan serologis IgM dan IgG Dengue pada anak penderita demam berdarah Dengue berdasarkan lama hari demam di RSUD Abdul Wahab Sjahranie Samarinda. Jurnal Kedokteran Mulawarman. 2018;5(2): 23-31.

2. Kementerian Kesehatan RI. Profil Kesehatan Indonesia tahun 2018. Jakarta: Kementerian Kesehatan Republik Indonesia, 2019.

3. Apriliana E, Tjiptaningrum A, Prayoga MJ. Hubungan hasil pemeriksaan antigen Non Struktural 1 (NS1) terhadap gejala, tanda klinis dan jumlah trombosit pada pasien suspek infeksi Dengue di RS Urip Sumoharjo. J Agromedicine. 2019;6(1): 30-7.
4. Ayu PR, Karima N, Gambaran pemeriksaan serologi IgM dan IgG Dengue dengan limfosit plasma biru pada pasien demam berdarah Dengue di RSUD Pesawaran Lampung. JK Unila. 2019;3(2): 247-50.

5. Megariani R, Mariko, Amrin A, Andani EP. Uji diagnostik pemeriksaan antigen nonstruktural 1 untuk deteksi dini infeksi virus Dengue pada anak. Sari Pediatri. 2014;16(2): 21-7.

6. Fajarani R, Martini, Adi MS. Gambaran variasi serotipe virus Dengue pada pasien infeksi Dengue di Kota Semarang Tahun 2019 (Penelitian di Rumah Sakit dan Puskesmas Kota Semarang). Jurnal Kesehatan Masyarakat (e-Journal). 2020; 8(1): 169-76.

7. Mayasari R, Arisanti M, Nurmaliani R, Sitorus H, Ambarita LP. Karakteristik penderita, hari dan curah hujan terhadap kejadian demam berdarah di Kabupaten Ogan Komering Ulu. JHECDs. 2019;5(1): 23-9. doi: 10.22435/jhecds.v5i1.1300.

8. Driyah S, Novriani H. Gambaran klinis dan serologi (IgM dan IgG) di tiga daerah endemik Pontianak Medan, dan Jakarta. J Indon Med Assoc. 2015;65(12): 612-7.

9. Mayasari R, Sitorus H, Salim M, Oktavia S, Supranelfy Y, Wurisastuti T. Karakteristik pasien Demam Berdarah Dengue pada instalasi rawat inap RSUD Kota Prabumulih periode Januari-Mei 2016. Media Litbangkes. 2019;29(1):39-50. doi:10.22435/mpk.v29i1.271.

10. Yanti CA, Novita. JM. Analisis kejadian DBD di Kota Bukittinggi. Epidemica (Journal of Public Health). 2020;1(1): 5-16. doi:10.35730/epidemica.v1i1.519.

11. Dayani DP. The overview of Dengue hemorrhagic fever in East Java during 20152017. Jurnal Berkala Epidemiologi. 2020;8(1): 35-41. doi: 10.20473/jbe.V8I12020.35-41.

12. Tawakal F, Azkiya A. Diagnosis penyakit Demam Berdarah Dengue (DBD) menggunakan metode Learning Vector Quantization (LVQ). JISKA. 2020;4(3):56-64.

13. Siskayani AS, Sumarya IM, Sari NLPK. Trombosit terendah, kenaikan hematokrit dan kadar TNF- $\alpha$ sebagai indikasi keparahan infeksi virus Dengue pada pasien DD dan DBD. WIDYA BIOLOGI. 2019;10(1): 13-22. 
14. Anastasia H. Diagnosis klinis Demam Berdarah Dengue di tiga kabupaten/kota Sulawesi Tengah Tahun 2015-2016. Jurnal Vektor Penyakit. 2018;12(2):77-86. doi:10.22435/vektorp.v12i2.834.

15. Mahasurya IGA, Lestari AAW, Yasa IWPS. Gambaran pemeriksaan serologi IgM-IgG anti Dengue pasien terinfeksi virus Dengue di Rumah Sakit Surya Husada Denpasar Bali pada periode Desember 2013 sampai Mei 2014. E-Jurnal Medika Udayana. 2017;6 (1):1-6.

16. Irwadi D, Arif M, Hardjoeno. Gambaran serologis IgM - IgG cepat dan hematologi rutin penderita DBD. Indonesian Journal Of Clinical Pathology and Medical Laboratory. 2007;13(2):45-8.

doi: 10.24293/ijcpml.v13i2.860.

17. Radji M. Imunologi dan virologi, edisi revisi. Jakarta: Isfi Penerbitan; 2015.
18. Mulyadi, Novelia M, Nugraheni N. Hubungan antara pemeriksaan antibodi Dengue $\mathrm{IgG}$ dengan uji fungsi hati (SGOT dan SGPT) pada pasien Demam Berdarah Dengue (DBD) di RSUD dr. M. Yunus Bengkulu bulan Desember 2015-Januari 2016. Jurnal Kedokteran Raflesia. 2016; 2(2):1-8.

19. Chandi DH. Prevalence of Dengue virus infection among population of Bhaili visiting tertiary health institution; Chhattisgarh. Asian Journal of Medical sciences. 2020; 11(2):30-4. doi: 10.3126/ajms.v11i2.27345.

20. Sukendra DM. Efek olahraga ringan pada fungsi imunitas terhadap mikroba patogen: infeksi virus Dengue. Jurnal Media Ilmu Keolahragaan Indonesia. 2015;5(2):57-65.

21. Trisnadewi NLM, Wande IN. Pola serologi IgM dan IgG pada infeksi Demam Berdarah Dengue (DBD) di Rumah Sakit Umum Pusat Sanglah, Denpasar, Bali bulan Agustus sampai September 2014. E-JURNAL MEDIKA, 2016; 5(8):1-5. 
BALABA Vol. 16 No. 2, Desember 2020: 209-216 